\title{
Epiphytic Colonization of Pear Stigmas and Hypanthia by Bacteria During Primary Bloom
}

\author{
V. O. Stockwell, R. J. McLaughlin, M. D. Henkels, J. E. Loper, D. Sugar, and R. G. Roberts
}

First, third, and fourth authors: U.S. Department of Agriculture, Agricultural Research Service, Horticultural Crops Research Laboratory, Corvallis, OR 97330; second and sixth authors: U.S. Department of Agriculture, Agricultural Research Service, Tree Fruit Research Laboratory, Wenatchee, WA 98801; fifth author: Oregon State University, Southern Oregon Research and Extension Center, Medford 97502. Current address of R. J. McLaughlin: 220 N. Western Ave., Wenatchee, WA 98801.

Accepted for publication 2 August 1999.

\begin{abstract}
Stockwell, V. O., McLaughlin, R. J., Henkels, M. D., Loper, J. E., Sugar, D., and Roberts, R. G. 1999. Epiphytic colonization of pear stigmas and hypanthia by bacteria during primary bloom. Phytopathology 89:11621168.

Pear blossoms were sampled during various stages of bloom in 1991 and 1992 from orchards at Cashmere, WA, and Corvallis and Medford, OR, for epiphytic populations of culturable bacteria. On stigmatic surfaces, bacteria were isolated from 2 to $32 \%$ of blossoms prior to petal expan-

gram-negative and -positive bacteria were identified from the Medford and Cashmere field sites. Pseudomonas syringae and Pseudomonas viridiflava were isolated from all sites and were the predominant species detected at Corvallis, where they were isolated from $28 \%$ of the blossoms sampled on a given date. Because most pear blossoms do not support detectable populations $\left(\geq 10^{2} \mathrm{CFU} / \mathrm{tissue}\right)$ of culturable bacteria prior to petal expansion, we speculate that introduced biocontrol agents may become established with minimal competition from indigenous epiphytes at early bloom stages.
\end{abstract} sion and from 47 to $94 \%$ of blossoms by petal fall. In general, a lower percentage of hypanthia than stigmas supported bacterial populations. Randomly selected bacteria isolated at population levels of $\geq 10^{4} \mathrm{CFU} / \mathrm{tis}-$ sue were identified by fatty acid methyl ester analysis. Diverse genera of
Additional keywords: biological control, Erwinia amylovora, fire blight, microbial ecology, Pyrus spp.
Bacteria inhabiting aerial plant surfaces influence plant health as pathogens, symbionts, and saprophytes that effect biological control of plant diseases $(1,3,14)$. It is now widely acknowledged that plant pathogenesis occurs within the context of indigenous microbial communities that can alter the outcome of plant-pathogen interactions before infection occurs. This may be particularly true for diseases caused by pathogens that have an epiphytic stage in their life cycle, such as many bacterial plant pathogens $(1,3,8)$. Consequently, many active research programs are directed toward characterization of bacterial strains that live epiphytically on plants, where they individually or conjointly suppress plant disease. Characterization of epiphytic bacteria has provided an important context for understanding the microbial competition and antagonism that plant pathogens encounter on foliar surfaces in field environments. Like leaves, blossoms serve as the infection courts for many plant diseases, yet little is known about the composition of microbial communities that inhabit blossom surfaces or the size or dynamics of indigenous microbial populations on these plant tissues.

Pear and apple blossoms are important infection courts for $\mathrm{Er}$ winia amylovora, the fire blight pathogen. E. amylovora grows primarily on stigmas, which have a moist and nutrient-rich surface, and infects a blossom through the hypanthium $(6,38,42)$. Certain strains of epiphytic bacteria, including strains of Pseudomonas fluorescens and Pantoea agglomerans, can reduce significantly

Corresponding author: V. O. Stockwell; E-mail address: stockwev@ bcc.orst.edu

V. O. Stockwell and R. J. McLaughlin are cofirst authors and contributed equally to the research.

Publication no. P-1999-1004-03R

This article is in the public domain and not copyrightable. It may be freely reprinted with customary crediting of the source. The American Phytopathological Society, 1999. the severity of fire blight if they are sprayed on blossoms prior to infection by $E$. amylovora $(11,13,19,20,30,40,41)$. For example, Pseudomonas fluorescens A506 reduces colonization of pear blossoms by E. amylovora through preemptive exclusion, whereby populations of A506 established on pear blossoms preclude the subsequent establishment of E. amylovora. Similarly, large populations of indigenous bacteria on surfaces of pear blossoms in an orchard may reduce establishment of E. amylovora or a bacterial antagonist applied during bloom. Bacteria other than E. amylovora are present on healthy pear and apple blossoms $(4,22,24,32,37)$, but little is known about the population sizes, distributions, or diversities of indigenous bacteria on these floral tissues. The objectives of our study were to characterize epiphytic populations of bacteria on stigmas and hypanthia of pear blossoms during primary bloom in three pome fruit-growing regions of the Pacific Northwest of the United States.

\section{MATERIALS AND METHODS}

Orchard sites. Sampling sites included a commercial orchard $6.5 \mathrm{~km}$ northwest of Cashmere, WA; an experimental orchard located at the Southern Oregon Research and Extension Center, Medford, OR; and an orchard composed of the Pyrus spp. collection located in the U.S. Department of Agriculture National Germplasm Repository, Corvallis, OR. The Cashmere and Medford sites are located within pome fruit-growing areas, whereas the Corvallis site is isolated from commercial orchards. None of the plots were sprayed with antibiotics during the course of the study; however, spray practices differed historically. The Medford orchard was sprayed routinely with streptomycin and oxytetracycline prior to the study. Streptomycin and oxytetracycline were applied at the Cashmere site 2 years prior to the beginning of the study. Antibiotic sprays had not been applied at the Corvallis site. 
The Cashmere site in 1991 consisted of 30 d'Anjou pear trees randomly chosen from within an 8 row $\times 19$ tree block. In 1992, the Cashmere field site consisted of 21 trees within the same block. The Corvallis plot consisted of 13 Bartlett pear trees located within an orchard containing a collection of Pyrus germ plasm. The Medford plot in 1991 consisted of 37 trees of Bartlett pear within an 8 row $\times 13$ tree block adjacent to a varietal pear block and a block of d'Anjou pears. Over-tree irrigation was used for frost protection at Medford in 1991. In 1992, the Medford site consisted of 20 Bartlett pear trees in a predominantly d'Anjou plot that lacked over-tree irrigation.

Weather data were recorded during the bloom period at each of the sampling sites. Data collected included mean hourly temperatures and precipitation. Data from the Oregon sites were obtained from AgriMet weather stations (Northwest Cooperative Agricultural Weather Network, Bonneville Power Administration and the U.S. Bureau of Reclamation, Boise, ID) located $\approx 1 \mathrm{~km}$ from experimental sites. At Cashmere, WA, data were obtained from a $21 \mathrm{X}$ micrologger (Campbell Scientific, Logan, UT) located $\approx 2.2 \mathrm{~km}$ from the orchard site. Temperature and leaf wetness sensors were placed 1 to $2 \mathrm{~m}$ above the orchard floor.

Culture media. In 1991, bacterial populations on blossoms were isolated on four media: $20 \%$ trypticase soy agar (TSA, Difco Laboratories, Detroit), nutrient broth-yeast extract-dextrose agar (25), 925 minimal medium agar plus $10 \%$ sucrose (15), and Pseudomonas agar F (Difco). All media used for bacterial counts were supplemented with cycloheximide (Sigma Chemical Co., St. Louis) at $50 \mu \mathrm{g} / \mathrm{ml}$ after autoclaving. Because the numbers and types of bacteria isolated from blossoms did not vary significantly among the media used in 1991, 20\% TSA was the only medium used for recovery of bacteria in 1992 .

Blossom sampling for microbial colonization. Blossoms chosen for sampling were located on the periphery of trees and $\approx 1$ to $2 \mathrm{~m}$ above the orchard floor. All blossoms were marked at the initial sampling date (1 to $10 \%$ bloom) with a sterile, plastic-coated colored wire or colored yarn tied around the peduncle. Petals on each marked blossom were partially expanded but covered the anthers and stigmas. Two to fifty blossoms were marked per tree, depending on the availability of blossoms at the appropriate stage of development. At each site, blossoms were fully open within $24 \mathrm{~h}$ after marking.

The initial sampling dates in each of the plots were 31 March 1991 and 16 March 1992 at Corvallis; 4 April 1991 and 21 March 1992 at Medford; and 29 April 1991 and 10 April 1992 at Cashmere. Blossoms were sampled every 2 to 4 days through petal fall. At each sampling date, 30 to 40 tagged blossoms were removed from trees with flame-sterilized forceps. At Medford and Cashmere in 1991, stigma and hypanthium tissues, without sepals or anthers, were put separately into sterile microcentrifuge tubes containing $1 \mathrm{ml}$ of sterile washing buffer $(10 \mathrm{mM}$ potassium phosphate buffer, $\mathrm{pH} 7.0,1 \%$ [wt/vol] Bacto Peptone [Difco]) at the orchard site. At Corvallis in 1991 and all sites in 1992, blossoms were placed in sterilized 12-well microtiter dishes and transported to the laboratory in an ice chest. Within $4 \mathrm{~h}$ of sampling, each blossom was dissected, and the stigmas and hypanthia were placed separately in test tubes containing $1 \mathrm{ml}$ of washing buffer. Samples in washing buffer were vortexed for 3 s, sonicated (model 3200, Branson, Shelton, CT) for $3 \mathrm{~min}$, and two 100-fold dilutions were made in washing buffer. Samples $(10 \mu \mathrm{l})$ from buffer containing tissue and from dilutions were spread on a single plate. The detection limit was $10^{2} \mathrm{CFU} /$ tissue. Plates were incubated at $24^{\circ} \mathrm{C}$ for 3 days for total bacteria counts. A single, spatially isolated colony was picked randomly from each plate, in which colony counts represented population sizes of $\geq 10^{4} \mathrm{CFU} /$ floral tissue. Colonies were subcultured twice for purity and preserved on silica gel at $-20^{\circ} \mathrm{C}$ or in $15 \%$ glycerol in nutrient broth at $-80^{\circ} \mathrm{C}$.

Identification of bacterial strains. Fatty acid methyl ester (FAME) analysis of whole-cell fatty acids was performed with selected strains isolated from dilutions representing population levels of $\geq 10^{4} \mathrm{CFU}$ on floral tissues. Fatty acid methyl esters were extracted from each isolate by standard and recommended procedures for gas chromatography FAME analysis (26). After extraction, samples were analyzed with a gas chromatograph (model 5890A, Hewlett-Packard Co., Avondale, PA) and Microbial Identification System software (Microbial ID Inc., Newark, DE) using the aerobe method. FAME analysis of each strain was done at least twice. Acceptance criteria for strain identification was an average match to a fatty acid profile of a known bacterium at 0.6 similarity or greater. Taxonomic classifications assigned by the system software were accepted at this specific level because pathovar designations were not consistent.

Additional classification methods were used to evaluate bacterial identifications based on FAME analyses that were questionable, e.g., if an isolate was identified as a fluorescent pseudomonad when it obviously was not fluorescent, if different names were assigned to an isolate when analyses were repeated, or if low similarity indices were obtained. Classification methods included tests for Gram differentiation, aerobiosis, presence of oxidase, catalase, and arginine dihydrolase, and utilization of various carbohydrates where appropriate (33). The pathogenicity of isolates identified as E. amylovora was evaluated by an immature pearslice assay (10).

Data analysis. Bacterial population size was determined separately for stigmatic and hypanthia tissues at each sampling date. Data were analyzed using SAS software, version 6.03 (SAS Institute, Cary, NC). In the experiment in which different media for isolating bacteria were compared, bacterial population sizes from each sample were categorized using a 0 to 3 scale $(0=$ no bacteria isolated; $1=10^{2} \leq x<10^{3} \mathrm{CFU} /$ tissue; $2=10^{3} \leq x<10^{4} \mathrm{CFU} /$ tissue; and $3=x \geq 10^{4} \mathrm{CFU} /$ tissue), and categorized data were evaluated by chi-square analyses. In all other experiments, bacterial population size on individual blossoms was estimated directly from colony counts, and estimates were logarithmically transformed to base 10 prior to calculation of mean population size. In some treatments, the population size of culturable bacteria was commonly below the detection limit of $100 \mathrm{CFU} /$ sample. Therefore, population data were presented as two values: isolation incidence, defined as percentage of blossoms that had population sizes of culturable bacteria exceeding the detection limit, and size of detectable populations, indicating the mean population size on those blossoms from which bacteria were detected. Taken together, the two values accurately represent the population data. Nevertheless, estimates of detectable population size presented here are not always directly comparable to population size estimates from data sets in which values from replicates below the detection limit are included.

\section{RESULTS}

Weather conditions at sampling sites. In 1991, rainfall was recorded almost every day during bloom at the Corvallis site (Fig. 1A). Cumulative rainfall and number of rainfall events in 1991 were lowest at the Cashmere site (Fig. 1A). Cashmere and Corvallis were warmer than Medford during bloom in 1991, as indicated by the cumulative number of degree hours at $>5^{\circ} \mathrm{C}$ (Fig. 1C). In 1991, there were frosts on days 4, 7, and 8 during the sampling period at Medford; on day 11 at Corvallis; and no frost during bloom at Cashmere.

Little rainfall was recorded during the sampling period in 1992 (Fig. 1B); however, dew was recorded on 10 of 13 days at Corvallis, on every morning at Medford, and on 12 of 15 days at Cashmere. In 1992, the Medford site was the warmest, and the Cashmere site was the coolest (Fig. 1D). Frosts occurred on day 15 at Medford; day 3 at Corvallis; and days 0, 1, 13, and 14 at Cashmere.

Isolation of bacteria from pear blossoms in Corvallis. On the initial sampling date in 1991 and 1992, few blossoms contained 
populations of bacteria. Isolation incidence (i.e., percentage of blossoms that had detectable population sizes of culturable bacteria) on stigmas increased over time from $2 \%$ on the first sampling date (day 0) to $80 \%$ on day 15 (1991) (Fig. 2A) and from $2 \%$ on day 0 to $48 \%$ on day 13 (1992) (Fig. 2C). Isolation incidence on hypanthia surfaces was fairly consistent throughout the sampling period within a given year at Corvallis. After petal expansion in 1991 , bacteria were isolated from 25 to $65 \%$ of the hypanthia

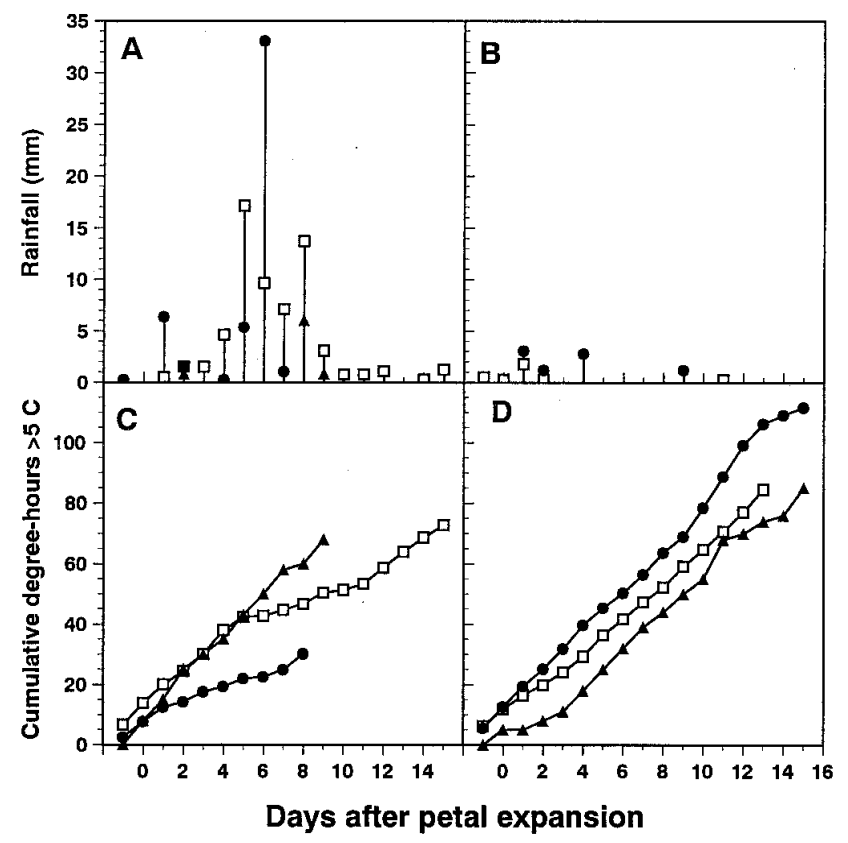

Fig. 1. Daily precipitation at Corvallis, OR ( $\square$ ), Medford, OR (๑), and Cashmere, WA (ム) in A, 1991 and B, 1992. Lower panels represent cumulative degree hours at $>5^{\circ} \mathrm{C}$ at the three orchard sites during bloom in C, 1991 and D, 1992.

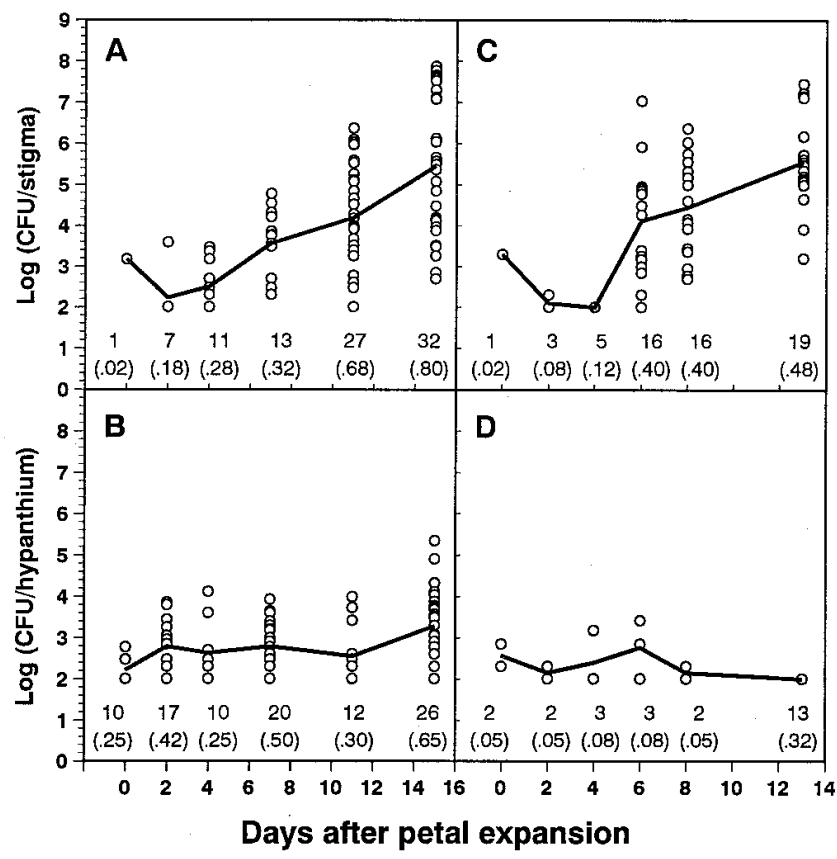

Fig. 2. Circles represent the population sizes of bacteria isolated on 20\% trypticase soy agar from $\mathbf{A}$ and $\mathbf{C}$, stigmas and $\mathbf{B}$ and $\mathbf{D}$, hypanthia from individual pear blossoms sampled in Corvallis, OR, in A and B, 1991 and $\mathbf{C}$ and D, 1992. Forty blossoms were sampled each time. Detection limit was $10^{2} \mathrm{CFU} /$ tissue. Numbers above the $\mathrm{x}$-axis represent the number of samples with populations of bacteria; parenthetical numbers represent isolation incidence. Solid lines depict the mean population sizes of bacteria on each sampling date. sampled (Fig. 2B). In 1992, bacteria were isolated from a smaller percentage of hypanthia (5 to 32\%) (Fig. 2D) compared with 1991. After petal expansion, isolation incidence was greater on stigmas than on hypanthia during both years.

At Corvallis in 1991 and 1992, the mean population size of bacteria on stigmas increased over time and exceeded $10^{5} \mathrm{CFU} / \mathrm{blos}-$ som by the end of the experiment (Fig. 2A and C). Population sizes of bacteria on stigmatic surfaces were greater than $10^{7} \mathrm{CFU}$ for some blossoms. In both years, mean population sizes on stigmas were greater than those on hypanthia of blossoms sampled six or more days after petal expansion. Mean bacterial population sizes ranged from $10^{2}$ to $10^{3} \mathrm{CFU} /$ hypanthium over both years and did not increase markedly with blossom age (Fig. 2B and D). In 1991 , the maximum bacterial population size on an individual hypanthium exceeded $10^{5} \mathrm{CFU}$, whereas the maximum population size was $4 \times 10^{3} \mathrm{CFU}$ in 1992 .

The composition and abundance of bacterial species isolated from floral tissues supporting population levels of $\geq 10^{4} \mathrm{CFU}$ were consistent over both years at Corvallis, even though weather conditions and detection incidence varied between years. Fluorescent pseudomonads, particularly Pseudomonas syringae, were the dominant species detected on blossoms in both 1991 and 1992 (Table 1). Pseudomonas fluorescens and Pseudomonas viridiflava also were isolated during both years. E. amylovora was isolated from two blossoms at 8 and 13 days after opening in 1992. E. amylovora isolates caused typical symptoms of fire blight (e.g., necrosis and ooze) on inoculated immature pear slices.

Isolation of bacteria from blossoms at Medford. A small proportion of blossoms (13\% in 1991 and 5\% in 1992) contained bacterial populations prior to petal expansion (Fig. 3). In 1991, isolation incidence of bacteria from stigmas increased from $3 \%$ on day 0 to $56 \%$ on day 2 (Fig. 3A). During that same time period, isolation incidence of bacteria from hypanthia also increased from 10 to $72 \%$ (Fig. 3B). Almost all of the stigmas and hypanthia sampled 8 days after blossom opening contained detectable bacterial populations in 1991 (Fig. 3A and B). On all sampling dates, isolation incidence of bacteria from pear blossoms at Medford was smaller in 1992 than in 1991. Isolation incidence of bacteria from stigmas in 1992 increased over time to a maximum of $65 \%$ on day 10 (Fig. 3C). Isolation incidence of bacteria from hypanthia varied from 5 to $20 \%$ during the course of the experiment (Fig. 3D).

The mean population sizes of bacteria isolated from stigmas ranged from $2 \times 10^{2}$ to $2 \times 10^{4} \mathrm{CFU} /$ blossom in 1991 and 1992 (Fig. 3A and $\mathrm{C}$ ). The largest bacterial population size on stigmas of an individual blossom was $4 \times 10^{6} \mathrm{CFU}$ in 1991 and $1 \times 10^{7} \mathrm{CFU}$ in 1992 . The mean bacterial population size isolated from hypanthia over

TABLE 1. Bacterial strains isolated from pear hypanthium $(\mathrm{H})$ and stigma $(\mathrm{S})$ tissues during primary bloom in Corvallis, OR

\begin{tabular}{|c|c|c|c|c|}
\hline $\begin{array}{l}\text { Year } \\
\text { Taxon }\end{array}$ & $\begin{array}{c}\text { SIM } \\
\text { range }^{\mathrm{a}}\end{array}$ & $\begin{array}{c}\text { Days } \\
\text { petal after } \\
\text { expansion }\end{array}$ & Tissue & $\begin{array}{c}\text { No. of } \\
\text { blossoms }^{b}\end{array}$ \\
\hline \multicolumn{5}{|l|}{1991} \\
\hline Pseudomonas fluorescens & $0.73-0.88$ & 7,11 & $\mathrm{~S}$ & 1 \\
\hline Pseudomonas syringae & $0.81-0.97$ & $7,11,15$ & S & $2-9$ \\
\hline Pseudomonas viridiflava & $0.65-0.76$ & $7,11,15$ & $\mathrm{~S}$ & $1-10$ \\
\hline \multicolumn{5}{|l|}{1992} \\
\hline Erwinia amylovora & $0.54-0.80$ & 8,13 & $\mathrm{~S}$ & 2 \\
\hline Pseudomonas fluorescens & $0.70-0.84$ & 6,13 & $\mathrm{~S}$ & 1 \\
\hline Pseudomonas syringae & $0.86-0.97$ & $6,8,13$ & $\mathrm{~S}$ & $6-11$ \\
\hline Pseudomonas viridiflava & $0.81-0.93$ & 6,13 & $\mathrm{H}, \mathrm{S}$ & $1-3$ \\
\hline Unidentified & $\mathrm{NA}^{\mathrm{c}}$ & 6 & S & 1 \\
\hline
\end{tabular}

a Similarity index ranges from bacterial identifications based primarily on gas chromatographic analysis of fatty acid methyl ester profiles. Positive identification of bacteria with similarity index values of $\leq 0.6$ was confirmed by biochemical and morphological tests.

b Number of blossoms from which a strain was isolated on a given sampling date. Forty blossoms were sampled per date.

c Not applicable. 
both years was fairly consistent and ranged from $1.2 \times 10^{2}$ to $2.5 \times$ $10^{3}$ CFU/blossom (Fig. 3B and D). The largest bacterial populations isolated from hypanthia of individual blossoms were $5 \times$ $10^{7}$ and $9 \times 10^{7} \mathrm{CFU}$ in 1991 and 1992, respectively; these population sizes were larger than those isolated from stigma samples at Medford.

The array of bacterial genera isolated from pear blossoms at Medford was more diverse than that isolated from Corvallis (Table 2). Fluorescent pseudomonads were isolated during both years from the Medford site (Table 2), but unlike the Corvallis site, Pseudomonas spp. were not the dominant species present on blossoms. Gram-positive bacteria were isolated in large populations from pear blossoms at Medford in 1991 and 1992. Two days after petal expansion at Medford in 1991, stigmatic surfaces of $30 \%$ of the blossoms were colonized by Arthrobacter spp., 20\% were colonized by unidentified gram-positive bacteria, and $10 \%$ contained large populations of Bacillus megaterium. These bacteria were not isolated at population levels of $10^{4} \mathrm{CFU} /$ sample from blossoms harvested later during bloom in 1991.

In 1992, fewer types of bacteria in large populations $\left(\geq 10^{4} \mathrm{CFU} /\right.$ sample) were present on blossoms than in 1991. Curtobacterium flaccumfaciens and Pseudomonas putida were isolated in large populations on only one sampling date in 1992 (Table 2). Pseudomonas syringae was detected in samples taken on days 6,10 , and 15 in 1992; isolation incidence ranged from 3 to 5\%. Pantoea agglomerans (previously called Erwinia herbicola) was isolated from stigmas on days 6 and 10. Unidentified gram-positive bacteria were isolated at large population levels from 8 to $25 \%$ of samples taken during late bloom; another gram-positive bacterium, Clavibacter michiganense, was isolated from up to $10 \%$ of samples taken during late bloom.

Isolation of bacteria from blossoms at Cashmere. Isolation incidence of bacteria from pear blossoms prior to petal expansion was greater at Cashmere in 1991 than for other sites and years. In $1991,32 \%$ of the stigma and $52 \%$ of the hypanthia samples contained detectable populations of bacteria on day 0 (Fig. 4A and B).

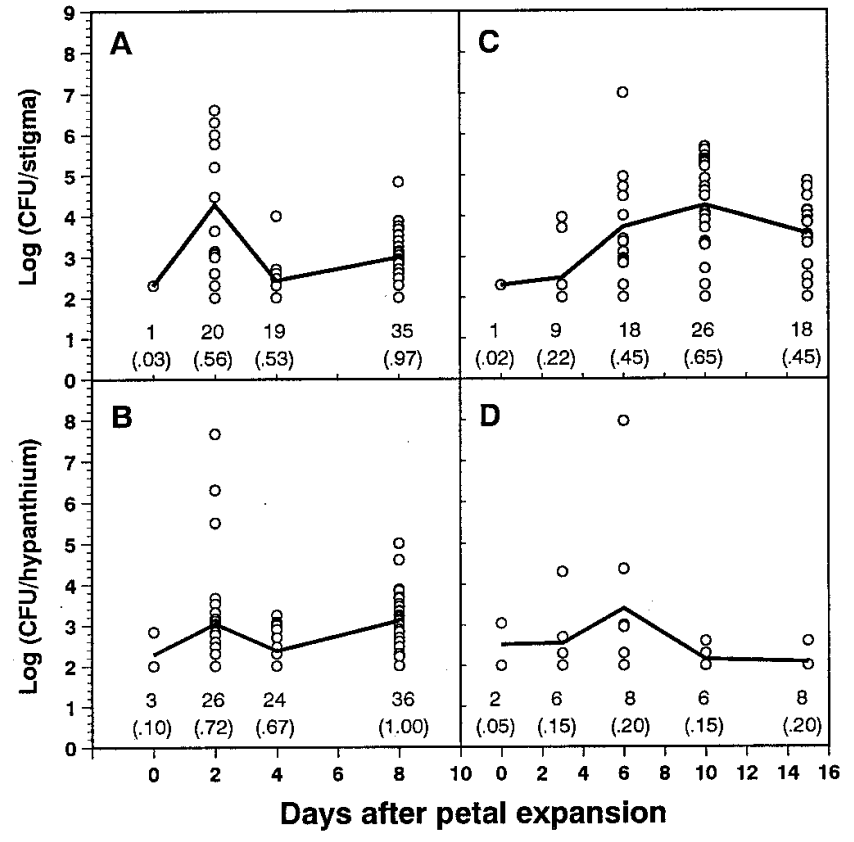

Fig. 3. Circles represent the population sizes of bacteria isolated on $20 \%$ trypticase soy agar from $\mathbf{A}$ and $\mathbf{C}$, stigmas and $\mathbf{B}$ and $\mathbf{D}$, hypanthia from individual pear blossoms sampled in Medford, OR, in A and B, 1991 and C and D, 1992. Thirty blossoms were sampled on day 0 in 1991, and forty blossoms were sampled on all other dates. Detection limit was $10^{2} \mathrm{CFU} /$ tissue. Numbers above the $\mathrm{x}$-axis represent the number of samples with populations of bacteria; parenthetical numbers represent isolation incidence. Solid lines represent the mean population sizes of bacteria on each sampling date.
In 1991, stigmas and hypanthia from the majority of blossoms sampled 2 days after petal expansion had detectable bacterial populations (Fig. 4A and B). In 1992, only 6\% of the stigmas and hypanthia sampled before petal expansion contained detectable bacterial populations (Fig. 4C and D). Isolation incidence of bacteria from stigmas and hypanthia in 1992 increased over time and reached

TABLE 2. Bacterial strains isolated from pear hypanthium $(\mathrm{H})$ and stigma (S) tissues during primary bloom in Medford, OR

\begin{tabular}{|c|c|c|c|c|}
\hline $\begin{array}{l}\text { Year } \\
\text { Taxon }\end{array}$ & $\begin{array}{c}\text { SIM } \\
\text { range }^{\mathrm{a}}\end{array}$ & $\begin{array}{c}\text { Days } \\
\text { after petal } \\
\text { expansion }\end{array}$ & Tissue & $\begin{array}{c}\text { No. of } \\
\text { blossoms }\end{array}$ \\
\hline \multicolumn{5}{|l|}{1991} \\
\hline Arthrobacter spp. & $0.65-0.76$ & 2 & $\mathrm{~S}$ & 12 \\
\hline Bacillus licheniformis & $0.30-0.44$ & 8 & $\mathrm{H}$ & 2 \\
\hline Bacillus megaterium & $0.65-0.79$ & 2 & $\mathrm{~S}$ & 4 \\
\hline Bacillus pumilis & 0.26 & 2 & $\mathrm{H}$ & 1 \\
\hline Pseudomonas fluorescens & 0.94 & 4,8 & $\mathrm{~S}$ & 1 \\
\hline Pseudomonas syringae & 0.96 & 4 & $\mathrm{~S}$ & 1 \\
\hline $\begin{array}{l}\text { Pseudomonas viridiflava } \\
\text { Unidentified }\end{array}$ & 0.70 & 2 & $\mathrm{H}$ & 1 \\
\hline Gram positive & $\mathrm{NA}^{\mathrm{c}}$ & 2 & $\mathrm{~S}$ & 8 \\
\hline Gram variable & NA & 8 & $\mathrm{H}, \mathrm{S}$ & 2 \\
\hline \multicolumn{5}{|l|}{1992} \\
\hline Clavibacter michiganense & $0.59-0.86$ & $3,10,15$ & $\mathrm{H}, \mathrm{S}$ & $1-4$ \\
\hline Curtobacterium flaccumfaciens & 0.60 & 10 & $\mathrm{~S}$ & 1 \\
\hline Pantoea agglomerans & & 6,10 & $\mathrm{~S}$ & 1 \\
\hline Pseudomonas putida & 0.73 & 10 & $\mathrm{~S}$ & 1 \\
\hline $\begin{array}{l}\text { Pseudomonas syringae } \\
\text { Unidentified }\end{array}$ & $0.89-0.95$ & $6,10,15$ & $\mathrm{H}, \mathrm{S}$ & $1-2$ \\
\hline Gram positive & NA & $6,10,15$ & $\mathrm{~S}$ & $3-10$ \\
\hline
\end{tabular}

a Similarity index ranges from bacterial identifications based primarily on gas chromatographic analysis of fatty acid methyl ester profiles. Positive identification of bacteria with similarity index values of $\leq 0.6$ was confirmed by biochemical and morphological tests.

b Number of blossoms from which a strain was isolated on a given sampling date. Forty blossoms were sampled per date.

c Not applicable.

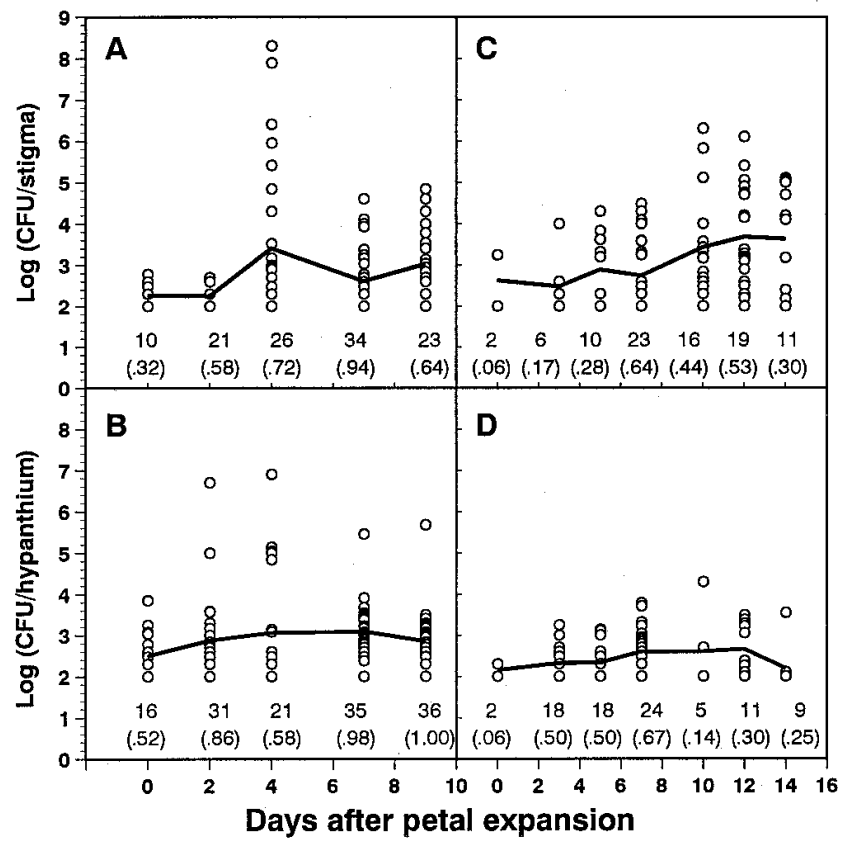

Fig. 4. Circles represent the population sizes of bacteria isolated on $20 \%$ trypticase soy agar from $\mathbf{A}$ and $\mathbf{C}$, stigmas and $\mathbf{B}$ and $\mathbf{D}$, hypanthia from individual pear blossoms sampled in Cashmere, WA, in A and B, 1991 and $\mathbf{C}$ and D, 1992. Thirty-one blossoms were sampled on day 0 in 1991, and thirty-six blossoms were sampled on all other dates. The detection limit was $10^{2} \mathrm{CFU} /$ tissue. Numbers above the $\mathrm{X}$-axis represent the number of samples with populations of bacteria; parenthetical numbers represent isolation incidence. Solid lines represent the mean population sizes of bacteria on each sampling date. 
a maximum of 64 to $67 \%$ on day 7 after petal expansion (Fig. 4C and D). In 1992, isolation incidence of bacteria on hypanthia was similar to or greater than incidence on stigmas during the first week after petal expansion, whereas in 1991 isolation incidence of bacteria from stigmas and hypanthia was similar.

At Cashmere in 1991 and 1992, the mean population sizes of bacteria on stigmas increased over time, reaching a maximum of $3 \times 10^{3} \mathrm{CFU}$ in 1991 and $5 \times 10^{4} \mathrm{CFU}$ in 1992 (Fig. 4A and C). Bacterial populations on stigmas were greater than $1 \times 10^{8} \mathrm{CFU}$ on individual blossoms on day 4 in 1991. In 1992, the maximum bacterial population size isolated from stigmas was $2 \times 10^{6} \mathrm{CFU} /$ stigma, nearly 100 -fold smaller than the population isolated during the previous year. Mean bacterial population sizes on hypanthia ranged from $5 \times 10^{2}$ to $1 \times 10^{3} \mathrm{CFU} /$ hypanthium over both years and generally did not increase over time (Fig. 4B and D). In 1991, the maximum bacterial population size on an individual hypanthium was $8 \times 10^{6} \mathrm{CFU}$ (Fig. 4B); in 1992, the maximum population size was $2 \times 10^{4} \mathrm{CFU} /$ hypanthium (Fig. 4D). In both years, mean population sizes on stigmas were equal to or greater than those on hypanthia.

At Cashmere, diverse bacterial genera were isolated at population levels of $\geq 10^{4} \mathrm{CFU}$ from one to four blossoms on single sampling dates during both years (Table 3). Arthrobacter spp., Pseudomonas syringae, Pseudomonas viridiflava, and other gram-negative and -variable isolates were isolated on more than one sample date in 1991. Five Pseudomonas spp. were isolated from stigmas from Cashmere in 1992: Pseudomonas fluorescens, Pseudomonas putida, and Pseudomonas syringae were present on 3 to $14 \%$ of stigmas on several sequential sampling dates.

\section{DISCUSSION}

The majority of pear blossoms sampled from orchards in three locations in the Pacific Northwest Region of the United States did

TABLE 3. Bacterial strains isolated from pear hypanthium $(\mathrm{H})$ and stigma $(\mathrm{S})$ tissues during primary bloom in Cashmere, WA

\begin{tabular}{|c|c|c|c|c|}
\hline $\begin{array}{l}\text { Year } \\
\text { Taxon }\end{array}$ & $\begin{array}{c}\text { SIM } \\
\text { range }^{\mathrm{a}}\end{array}$ & $\begin{array}{l}\text { Days } \\
\text { after petal } \\
\text { expansion }\end{array}$ & Tissue & $\begin{array}{c}\text { No. of } \\
\text { blossoms }\end{array}$ \\
\hline \multicolumn{5}{|l|}{1991} \\
\hline Arthrobacter spp. & 0.46 & $2,4,9$ & $\mathrm{H}, \mathrm{S}$ & 1 \\
\hline Bacillus pumilis & $0.40-0.52$ & 2 & $\mathrm{H}$ & 1 \\
\hline Clavibacter michiganense & $0.49-0.65$ & 4 & $\mathrm{~S}$ & 1 \\
\hline Curtobacterium flaccumfaciens & $0.27-0.39$ & 9 & $\mathrm{~S}$ & 1 \\
\hline Klebsiella terrigena & $0.52-0.53$ & 4 & $\mathrm{~S}$ & 1 \\
\hline Pseudomonas syringae & $0.53-0.94$ & 7,9 & $\mathrm{~S}$ & 1 \\
\hline Pseudomonas viridiflava & $0.86-0.94$ & 2,4 & $\mathrm{H}$ & 1 \\
\hline \multicolumn{5}{|l|}{ Unidentified } \\
\hline Gram negative & $\mathrm{NA}^{\mathrm{c}}$ & 2,9 & $\mathrm{H}, \mathrm{S}$ & 1 \\
\hline Gram positive & NA & 4 & $\mathrm{H}, \mathrm{S}$ & 4 \\
\hline Gram variable & NA & $2,7,9$ & $\mathrm{H}, \mathrm{S}$ & 1 \\
\hline \multicolumn{5}{|l|}{1992} \\
\hline Bacillus polymyxa & $0.20-0.24$ & 3 & $\mathrm{~S}$ & 1 \\
\hline Micrococcus kristinae & 0.87 & 14 & $\mathrm{~S}$ & 1 \\
\hline Pseudomonas chlororaphis & $0.86-0.92$ & 10 & $\mathrm{~S}$ & 1 \\
\hline Pseudomonas fluorescens & $0.55-0.82$ & 12,14 & $\mathrm{~S}$ & 1 \\
\hline Pseudomonas putida & $0.70-0.86$ & $10,12,14$ & $\mathrm{~S}$ & $1-3$ \\
\hline Pseudomonas syringae & $0.80-0.95$ & $5,10,12,14$ & $\mathrm{~S}$ & $1-5$ \\
\hline Pseudomonas viridiflava & 0.81 & 7 & $\mathrm{~S}$ & 2 \\
\hline \multicolumn{5}{|l|}{ Unidentified } \\
\hline Gram positive & NA & 7,14 & $\mathrm{~S}$ & 1 \\
\hline Gram uncertain & NA & 7 & $\mathrm{~S}$ & 1 \\
\hline
\end{tabular}

${ }^{a}$ Similarity index ranges from bacterial identifications based primarily on gas chromatographic analysis of fatty acid methyl ester profiles. Positive identification of bacteria with similarity index values of $\leq 0.6$ was confirmed by biochemical and morphological tests.

${ }^{b}$ Number of blossoms from which a strain was isolated on a given sampling date. Thirty-six blossoms were sampled per day.

c Not applicable. not support bacterial populations prior to petal expansion. In five of six field experiments, $<15 \%$ of the blossoms at this stage of development supported bacterial populations. Within a few days of petal expansion, however, bacteria were detected on stigmas or hypanthia of a substantial percentage (up to 86\%) of blossoms. These observations substantiate those of Manceau et al. (22), who reported that the population size of certain bacteria on pear blossoms increased throughout the bloom period. Bacteria present on blossoms prior to petal expansion may have overwintered within floral buds $(2,18,28)$. Sources of inoculum for colonization of blossoms after petal expansion include bacterial cells present on neighboring blossoms or leaves, bacteria growing epiphytically on weeds $(16,17,21)$ or crops grown in the vicinity, or bacteria present in rain or surface water used for overhead irrigation or frost protection.

In general, both the percentage of stigmas with bacterial populations and the mean population size of bacteria on stigmatic surfaces increased with blossom age. The percentage of hypanthia containing bacterial populations also increased with blossom age. In contrast, mean population size on hypanthia did not increase markedly with blossom age but fluctuated between $10^{2}$ to $10^{4} \mathrm{CFU/}$ hypanthia. Mean bacterial population sizes on stigmas generally were greater than those isolated from the hypanthia of blossoms sampled six or more days after petal expansion. In several of the field experiments, however, the maximum population size detected on an individual hypanthium was similar to the maximum population size detected on stigmas from an individual blossom. Therefore, although stigmas appear to be preferred over hypanthia as sites for bacterial colonization, a small proportion of hypanthia supported large populations of epiphytic bacteria.

The estimated population size of bacteria on stigmatic surfaces and hypanthia of individual pear blossoms varied strikingly among blossoms. For example, bacterial population size commonly varied by 10,000- to 100,000-fold among individual blossoms sampled at a given time. The range in population size of epiphytic bacteria among individual blossoms is comparable to the range observed with inoculated strains of Pseudomonas fluorescens and E. amylovora on blossoms sampled from orchards in Oregon and California $(11,20,35,36,39)$ or epiphytes on leaf surfaces of fieldgrown plants (7).

Weather undoubtedly caused some of the variation in bacterial population size that was observed among field sites, years, and sampling dates. In 1991, a year marked by frequent rainfall, both isolation incidence and mean population size of bacteria increased with blossom age at all three locations. In 1992, when rain was less frequent, the percentage of blossoms with populations was lower, but the mean population size on stigmas was similar to that observed in 1991. At petal fall at Corvallis, for example, only $48 \%$ of blossoms in 1992 (day 13) had bacterial populations, in contrast to $88 \%$ in 1991 (day 15), although the mean population size on stigmatic surfaces was similar for both years. These data suggest that conditions in 1992 were not conducive for dispersal of bacteria but allowed for growth and survival of bacteria that were deposited and established on stigmatic surfaces.

Frost is another factor that may have influenced bacterial population size on pear blossoms. For example, at Corvallis in 1992, both the percentage of blossoms with detectable populations and mean population size were low on days 2 and 4 and increased markedly on day 6. The increase could not be explained by rainfall or daytime temperatures, but a frost that occurred on day 3 may have contributed to increased bacterial population sizes. Increases in population sizes of total bacteria (12) or ice-nucleation active strains of Pseudomonas syringae (5) have been observed after frosts in the field, and such increases have been attributed to the release of nutrients from injured plant cells (9). Nevertheless, frost events were not followed consistently by increases in bacterial population sizes on pear blossoms in our study. Mean bacterial population size did not increase after frost events on days 4 , 
7, and 8 at Medford in 1991 or on days 13 and 14 at Cashmere in 1992. Freezing of the specific blossoms sampled in the study was not recorded, and it is possible that blossoms at these field sites supercooled and, therefore, avoided frost injury. Because frost injury, rather than subfreezing temperatures, is associated with increases in the population size of epiphytic bacteria (9), blossoms that avoided frost injury would not be expected to support larger epiphytic bacterial populations. Physical factors that varied with space and time among field sites probably influenced bacterial populations; however, specific environmental factors and their individual and interactive effects are unknown.

Fluorescent pseudomonads comprised the major group of bacteria detected at large population sizes (i.e., $\geq 10^{4} \mathrm{CFU} / \mathrm{blossom}$ ) at Corvallis during both years of the study. Pseudomonas syringae, described previously as a dominant component of the natural pear microflora $(22,28,31)$, commonly was present in large populations at Corvallis and also was detected sporadically at Medford and Cashmere. The Corvallis orchard was located next to a bean field, which may have contributed inoculum of Pseudomonas syringae and Pseudomonas viridiflava that became established on pear floral tissues. The pathogenicity and ice-nucleation activities of these bacteria were not evaluated, but sampled blossoms did not exhibit symptoms of blossom blast associated with infection by Pseudomonas syringae. In contrast to the Corvallis site, diverse species of bacteria present at population levels of $\geq 10^{4} \mathrm{CFU} / \mathrm{blos}-$ som were isolated on various sampling dates at Medford and Cashmere. Bacteria present in pond water, which was applied to the Medford orchard for frost protection in 1991 on days 4, 7, and 8, may have been among the strains isolated from pear blossoms that year. In both 1991 and 1992, gram-positive bacteria were more prevalent at Medford than at the other two field locations.

Absence of large populations (i.e., $\geq 10^{4} \mathrm{CFU}$ ) of E. amylovora and Pantoea agglomerans from blossoms on most sampling dates was conspicuous in view of several reports documenting epiphytic colonization of blossoms and other fruit tree tissues by these species $(11,13,27,35,36,38-40,43)$. For example, E. amylovora was isolated from $85 \%$ of pear blossoms sampled during 1970 to 1974 in California and during 1980 to 1983 in Utah (38) but was detected on only two sampling dates at the Corvallis site in our study. Although E. amylovora was isolated from blossoms at the Corvallis site, temperatures during bloom were below the threshold for a low risk of fire blight ( $<100$ units), according to the fire blight disease risk assessment model Cougarblight (34). At two sites, Cashmere (1991) and Medford (1992), temperatures were sufficiently high to warrant a moderate and extreme risk of fire blight, respectively. Therefore, the lack of detection of E. amylovora at the Cashmere and Medford sites could not be attributed solely to environmental conditions that limited growth or dispersal of the bacterium. Pantoea agglomerans has been isolated from apple tree tissues $(10,13,29,43)$, and when sprayed on trees during primary bloom, it effectively colonizes pear and apple blossoms $(11,13,30,35,36,43)$. Pantoea agglomerans strain C9-1 commonly established populations of between $10^{4}$ and $10^{6} \mathrm{CFU} /$ blossom on a majority of inoculated pear blossoms after spray-inoculation on pear trees in orchards located in the vicinity of each of the three orchards included in our study $(11,30,35,36)$. Large populations of indigenous Pantoea agglomerans were detected infrequently in the study, however, indicating that inoculum of indigenous strains, rather than environmental conditions conducive to growth of Pantoea agglomerans, was limiting.

Due to the low incidence of bacteria on pear blossoms during early bloom, we speculate that E. amylovora could become established with minimal competition from indigenous epiphytes at early stages of floral development. Soon after petal expansion, however, indigenous microorganisms were present on stigmatic surfaces and hypanthia. If these strains inhibit the growth of E. amylovora on floral surfaces, they could provide natural suppression of fire blight. Certain strains of Pseudomonas spp. isolated from Corval- lis reduced symptoms caused by E. amylovora in an immature pearslice assay (23) and could be effective antagonists of fire blight in the field. In contrast, few bacterial strains isolated from Medford or Cashmere reduced disease severity in the immature pear-slice assay (R. J. McLaughlin and R. G. Roberts, unpublished data). In a concomitant study on colonization of pear blossoms by fungi and yeast, R. J. McLaughlin and R. G. Roberts (unpublished data) found that filamentous fungi and yeast were recovered from a majority of blossoms (45 to 90\%) sampled by petal fall and that these organisms colonized hypanthia at an incidence similar to that on stigmas. Although the antagonistic activities of yeast and fungi have not been evaluated, their prevalence on hypanthia of pear blossoms warrants further investigation into their potential as biocontrol agents.

Established populations of indigenous bacteria on pear blossoms could suppress growth of introduced bacteria through preemptive exclusion $(19,41)$. The presence of sizable bacterial populations on stigmatic surfaces of pear, for example, could diminish the successful establishment of bacterial antagonists, such as Pseudomonas fluorescens A506 $(11,19,20,30,35,36,41)$ or Pantoea agglomerans C9-1 $(11,30,35,36)$, that would otherwise establish large populations on stigmatic surfaces. Given the assumption that inhibition of applied antagonists by indigenous bacteria could occur, the results of our study argue that such antagonists should be applied at early bloom, when few blossoms support epiphytic populations of indigenous bacteria.

\section{ACKNOWLEDGMENTS}

Research was supported by the USDA Agricultural Research Service, the Washington State Tree Fruit Research Commission, and the Winter Pear Control Committee. We thank J. Duffy, S. Reymond, C. Neuman, and S. Carnegie for excellent technical assistance and J. Postman for assistance in setting up the field plots at the USDA/ARS National Germplasm Repository in Corvallis, OR.

\section{LITERATURE CITED}

1. Andrews, J. H., and Hirano, S. S. 1991. Microbial Ecology of Leaves. Springer-Verlag, New York.

2. Andrews, J. H., and Kenerley, C. M. 1980. Microbial populations associated with buds and young leaves of apple. Can. J. Bot. 58:847-855.

3. Beattie, G. A., and Lindow, S. E. 1995. The secret life of foliar bacterial pathogens on leaves. Annu. Rev. Phytopathol. 33:145-172.

4. Beer, S. V., and Opgenorth, D. C. 1976. Erwinia amylovora on fire blight canker surfaces and blossoms in relation to disease occurrence. Phytopathology 66:317-322.

5. Gross, D. C., Cody, Y. S., Proebsting, E. L., Radamaker, G. K., and Spotts, R. A. 1983. Distribution, population dynamics, and characteristics of ice nucleation-active bacteria in deciduous fruit tree orchards. Appl. Environ. Microbiol. 46:1370-1379.

6. Hattingh, M. J., Beer, S. V., and Lawson, E. W. 1986. Scanning electron microscopy of apple blossoms colonized by Erwinia amylovora and E. herbicola. Phytopathology 76:900-904.

7. Hirano, S. S., Clayton, M. K., and Upper, C. D. 1994. Estimation of and temporal changes in means and variances of populations of Pseudomonas syringae on snap bean leaflets. Phytopathology 84:934-940.

8. Hirano, S. S., and Upper, C. D. 1990. Population biology and epidemiology of Pseudomonas syringae. Annu. Rev. Phytopathol. 28:155-177.

9. Hirano, S. S., and Upper, C. D. 1995. Ecology of ice nucleation-active bacteria. Pages 41-61 in: Biological Ice Nucleation and Its Applications. R. E. Lee, Jr., G. J. Warren, and L. V. Gusta, eds. The American Phytopathological Society, St. Paul, MN.

10. Ishimaru, C. A., Klos, E. J., and Brubaker, R. R. 1988. Multiple antibiotic production by Erwinia herbicola. Phytopathology 78:746-750.

11. Johnson, K. B., Stockwell, V. O., McLaughlin, R. J., Sugar, D., Loper, J. E., and Roberts, R. G. 1993. Effect of bacterial antagonists on establishment of honey bee-dispersed Erwinia amylovora in pear blossoms and on fire blight control. Phytopathology 83:995-1002.

12. Kaneda, T. 1986. Seasonal population changes and characterization of ice-nucleating bacteria in farm field of central Alberta. Appl. Environ. Microbiol. 52:173-178.

13. Kearns, L. P., and Hale, C. N. 1993. Biological control of fire blight by Erwinia herbicola: Survival of applied bacteria in orchard and glasshouse 
trials. Acta Hortic. 338:333-337.

14. Kinkel, L. L. 1997. Microbial population dynamics on leaves. Annu. Rev. Phytopathol. 35:327-347.

15. Langley, R. A., and Kado, C. I. 1972. Studies on Agrobacterium tumefaciens. Conditions for mutagenesis by $N$-methyl- $N^{\prime}$-nitro- $N$-nitrosoguanidine and relationships of $A$. tumefaciens to crown gall tumor induction. Mutation Res. 14:277-286.

16. Lattore, B. A., and Jones, A. L. 1979. Evaluation of weeds and plant refuse as potential sources of inoculum of Pseudomonas syringae in bacterial canker of cherry. Phytopathology 69:1122-1125.

17. Leben, C. 1965. Epiphytic microorganisms in relation to plant disease. Annu. Rev. Phytopathol. 3:203-230.

18. Leben, C. 1972. Micro-organisms associated with plant buds. J. Gen. Microbiol. 71:327-331.

19. Lindow, S. E. 1984. Integrated control and role of antibiosis in biological control of fire blight and frost injury. Pages 83-115 in: Biological Control on the Phylloplane. C. Windels and S. E. Lindow, eds. The American Phytopathological Society, St. Paul, MN.

20. Lindow, S. E., McGourty, G., and Elkins, R. 1996. Interactions of antibiotics with Pseudomonas fluorescens strain A506 in the control of fire blight and frost injury to pear. Phytopathology 86:841-848.

21. Malvick, D. K., and Moore, L. W. 1988. Population dynamics and diversity of Pseudomonas syringae on maple and pear trees and associated grasses. Phytopathology 78:1366-1370.

22. Manceau, C., Lalande, J.-C., Lachaud, G., Chartier, R., and Paulin, J.-P. 1990. Bacterial colonization of flowers and leaf surfaces of pear trees. Acta Hortic. 273:73-82.

23. McLaughlin, R. J., and Roberts, R. G. 1993. Laboratory and field assays for biological control of fire blight in d'Anjou pear. Acta Hortic. 338: 317-319.

24. McLaughlin, R. J., Roberts, R. G., Stockwell, V. O., Loper, J. E., and Sugar, D. 1992. Natural colonization of pear flower tissues during primary bloom. (Abstr.) Phytopathology 82:1067.

25. McLaughlin, R. J., Wisniewski, M. E., Wilson, C. L., and Chalutz, E. 1990. Effect of inoculum concentration and salt solutions on biological control of postharvest diseases of apple with Candida sp. Phytopathology 80: 456-461.

26. Miller, L., and Berger, T. 1985. Bacterial identification by gas chromatography of whole cell fatty acids. Hewlett-Packard application note 22841. Hewlett-Packard Co., Avondale, PA.

27. Miller, T. D., and Schroth, M. N. 1972. Monitoring the epiphytic population of Erwinia amylovora on pear with a selective medium. Phytopathology 62:1175-1182.

28. Montesinos, E., and Vilardell, P. 1991. Relationships among population levels of Pseudomonas syringae, amount of ice nuclei, and incidence of blast of dormant flower buds in commercial pear orchards in Catalunya,
Spain. Phytopathology 81:113-119.

29. Naumann, K., and Gierz, R. 1992. Studies on the colonization of apple leaves, flowers and twigs by epiphytic microorganisms. Zentralbl. Mikrobiol. 147:355-367.

30. Nuclo, R. L., Johnson, K. B., Stockwell, V. O., and Sugar, D. 1998. Secondary colonization of pear blossoms by two bacterial antagonists of the fire blight pathogen. Plant Dis. 82:661-668.

31. Psallidas, P. G., and Argyropoulou, A. 1992. Bacterial isolates from citrus and pear microflora antagonistic to ice nucleation active Pseudomonas syringae pv. syringae strains. Pages 259-265 in: Biological Control of Plant Diseases: Progress and Challenges for the Future. E. C. Tjamos, G. C. Papavizas, and R. J. Cook, eds. NATO ASI Series A, Life Sciences, vol. 230. Plenum Press, New York.

32. Pusey, P. L. 1999. Effect of nectar on microbial antagonists evaluated for use in control of fire blight of pome fruits. Phytopathology 89:39-46.

33. Smiebert, R. M., and Krieg, N. R. 1981. Systematics: General characterization. Pages 409-443 in: Manual of Methods for General Bacteriology. P. Gerhardt, ed. American Society of Microbiologists, Washington, DC.

34. Smith, T. J. 1996. A risk assessment model of fire blight of apple and pear. Acta Hortic. 411:97-104.

35. Stockwell, V. O., Johnson, K. B., and Loper, J. E. 1996. Compatibility of bacterial antagonists of Erwinia amylovora with antibiotics used to control fire blight. Phytopathology 86:834-840.

36. Stockwell, V. O., Johnson, K. B., and Loper, J. E. 1998. Establishment of bacterial antagonists of Erwinia amylovora on pear and apple blossoms as influenced by inoculum preparation. Phytopathology 88:506-513.

37. Sutton, T. B., and Jones, A. L. 1975. Monitoring Erwinia amylovora populations on apple in relation to disease incidence. Phytopathology 65: 1009-1012.

38. Thomson, S. V. 1986. The role of the stigma in fire blight infection. Phytopathology $76: 476-482$.

39. Thomson, S. V., Schroth, M. N., Moller, W. J., and Reil, W. O. 1975. Occurrence of fire blight of pears in relation to weather and epiphytic populations of Erwinia amylovora. Phytopathology 65:353-358.

40. Wilson, M., Epton, H. A. S., and Sigee, D. C. 1989. Interactions between Erwinia herbicola and E. amylovora on the stigma of hawthorn blossoms. Phytopathology 82:914-918.

41. Wilson, M., and Lindow, S. E. 1993. Interactions between the biological control agent Pseudomonas fluorescens strain A506 and Erwinia amylovora in pear blossoms. Phytopathology 83:117-123.

42. Wilson, M., Sigee, D. C., and Epton, H. A. S. 1989. Erwinia amylovora infection of hawthorn blossom: II. The Stigma. J. Phytopathol. 127:15-28.

43. Wodzinski, R. S., Sobiczewski, P., and Beer, S. V. 1987. Survival of an introduced strain and natural populations of Erwinia herbicola on apple. Acta Hortic. 217:245-251. 